\title{
Antitrust Private Enforcement and the Binding Effect of Public Enforcement Decisions*
}

\author{
Miguel Sousa Ferro ${ }^{\star *}$
}

\begin{abstract}
This paper provides an overview of the legal status quo in the European Union relating to the binding effect, in follow-on competition law cases, of public enforcement decisions, as well as of some of the legal issues which are likely to be the subject of controversy in years to come, in this regard. It tackles decisions declaring antitrust infringements adopted by the European Commission and by national competition authorities, as well as commitment decisions and decisions declaring infringements of merger control and State aid rules. It discusses the material, subjective and temporal scope of the binding effect. It also tackles other issues, such as the obligations of national courts relating to non-infringement decisions and ongoing investigations, and the issue of negative declarations. Finally, it looks into the arguments which may be put forward by litigants before national courts to avoid or circumvent the binding effect of public enforcement decisions. It is argued that the case-law already provides answers to many of the issues which are likely to be raised, which one may arrive at through a systematic and coherent interpretation of the general principles of EU Law, as clarified by the Court.
\end{abstract}

KEYWORDS: Antitrust; Competition Law; Merger Control; State Aid; Private Enforcement

\footnotetext{
* Date of reception: 18 September 2019. Date of acceptance: 20 September 2019. DOI: https://doi.org/10.7559/mclawreview.2019.1830.

** Professor at University of Lisbon Law School and at Universidade Europeia (Lisbon). Email: miguelferro@fd.ulisboa.pt. The author thanks Barry Rodger, Christian Kersting and Francisco Marcos for comments on a draft of this paper. All opinions and errors are the author's exclusive responsibility. In compliance with ASCOLA's Transparency and Disclosure Declaration, the author discloses that he represents plaintiffs in pending collective and individual antitrust damages actions in Portugal, including in the Cogeco case, mentioned in the present paper.
} 


\section{Introduction}

In the transposition of the Damages Directive ${ }^{1}$ across most Member States (MS), one issue above all seemed to raise eyebrows and lead to heated discussions: the binding effect of NCA decisions declaring infringements of Articles 101/102 TFEU. This article is meant to discuss what was, what is and what might be, in this regard. Case-law provides us already with a significant number of direct and indirect clarifications on this issue. The article will first look at the binding effect arising from European Commission (EC) decisions (section 2) and NCA decisions, before and after the Damages Directive (section 3). It will then delve deeper into the material, subjective and temporal scopes of these binding effects (section 4, 5 and 6). The obligations of national courts in the case of non-final infringement decisions (section 7) and of ongoing investigations (section 8) will also be discussed. And since there is more to Competition Law than just infringement decisions, sections 9 to 11 will discuss the binding effects arising from State aid decisions, merger control decisions and commitment decisions. Finally, section 12 will provide an overview of the debate on the possible limits to this binding effect and, ultimately, to the very primacy of EU Law.

\section{European Commission infringement decisions}

Under Article 16(1) of Regulation (EC) 1/2003 ("Reg. 1/2003"), ${ }^{2}$ European Commission ("EC") decisions identifying infringements of Article 101 or 102 of the Treaty on the Functioning of the European Union ("TFEU"), which have become final (res judicata), are binding upon national courts in follow-on private enforcement actions. ${ }^{3}$ This was largely a codification of obligations that already arose from general principles of EU Law (separation of powers, direct effect, principles of sincere cooperation and legal certainty), as clarified by the Court. ${ }^{4}$

\footnotetext{
${ }^{1}$ Directive 2014/104/EU of the European Parliament and of the Council of 26 November 2014 on certain rules governing actions for damages under national law for infringements of the competition law provisions of the Member States and of the European Union (OJ L 349/1, 05/12/2014).

${ }^{2}$ Council Regulation (EC) No. 1/2003 of 16 December 2002 on the implementation of the rules on competition laid down in Articles 81 and 82 of the Treaty (OJ L 1/1, 04/01/2003).

${ }^{3}$ Although the Regulation itself does not mention the requirement that the decision be final, the case-law does assert this requirement, clearly distinguishing the effects of final and non-final decisions. Some MS (e.g., France, Romania and the UK) technically infringe EU Law by reproducing this obligation in their own national legislation.

${ }^{4}$ Primarily: Judgment of the Court of 14 December 2000, Masterfoods Ltd v. HB Ice Cream Ltd, Case C-344/98, EU:C:2000:689, paragraphs 45-52, 56 and 60. See also: Judgment of 28 February 1991, Stergios Delimitis v. Henninger Bräu AG, Case C-234/89, EU:C:1991:91, paragraphs 44-55;
} 
Although Regulation 1/2003 only mentions infringement decisions (i.e. positive declarations), the ratio of Masterfoods ${ }^{5}$ applies equally to the decisions with findings of inapplicability (negative declarations) foreseen in Article 10 of Regulation 1/2003, ${ }^{6}$ creating an incentive for undertakings accused of antitrust infringement in private litigation to seek such a decision from the EC. ${ }^{7}$

A national court can only escape this binding effect of EC decisions if it believes that decision to be invalid and the CJEU declares this in a referral. ${ }^{8}$

\section{NCA infringement decisions}

\subsection{Independently from the Damages Directive}

Despite the transposition of the Damages Directive, it is still important to know the effects, in follow-on private enforcement actions, of NCA decisions identifying infringements of Article 101 or 102 TFEU, due to the Directive's temporal scope, and because the obligation arising from it only applies to actions for damages. ${ }^{9}$

Prior to the Damages Directive, there was no provision of positive EU Law governing this issue. However, it is settled that national rules

Advocate General Van Gerven's Opinion delivered on 27 October 1993, H. J. Banks \& Co. Ltd v. British Coal Corporation, Case C-128/92, EU:C:1993:860, paragraph 56; Judgment of 10 April 2008, Deutsche Telekom AG v. Commission of the European Communities, Case T-271/03, EU:T:2008:101, paragraph 120; Judgment of 14 October 2010, Deutsche Telekom AG v. European Commission, Case C-280/08 P, EU:C:2010:603, paragraph 90; Judgment of 6 November 2012, Europese Gemeenschap v. Otis NV and Others, Case C-199/11, EU:C:2012:684, paragraphs 50-54; Judgment of 25 November 2014, Orange v. European Commission, Case T-402/13, EU:T:2014:991, paragraph 27; Judgment of 23 November 2017, Gasorba SL and Others v. Repsol Comercial de Productos Petroliferos SA, Case C-547/16, EU:C:2017:891, paragraphs 23-24 and 29.

${ }^{5}$ Judgment of the Court of 14 December 2000, Masterfoods Ltd v. HB Ice Cream Ltd, Case C-344/98, EU:C:2000:689.

${ }^{6}$ See also recital 14 of Regulation (EC) 1/2003.

${ }^{7}$ In this sense, see: Alexander Schaub, "Panel one discussion: Compatibility, efficiency, legal scrutiny", in European Competition Law Annual 2000: The Modernisation of EC Antitrust Policy, eds. Claus-Dieter Ehlermann and Isabela Atanasiu (England: Hart Publishing, 2001), 35. Nina Bucan Gutta, The Enforcement of EU Competition Rules by Civil Law (Maklu Pub, 2014), 138.

${ }^{8}$ Judgment of 22 October 1987, Foto-Frost v. Hauptzollamt Lübeck-Ost, 314/85 EU:C:1987:452.

${ }^{9}$ Expectably, similar questions are already being raised about the binding effect of decisions of national authorities entrusted with applying other areas of EU Law - see pending Case C-546/18 Adler Real Estate. 
concerning burden of proof may need to be adjusted as a result of the principle of effectiveness of EU Law. ${ }^{10}$

The CJEU was asked to clarify the impact of this principle in Cogeco. The Court did not need to reply, ${ }^{11}$ but AG Kokott argued that the exercise of the right to compensation conferred by Article 102 TFEU would be made excessively difficult if no effect were recognised to the decisions of the MS's own NCA, given the "special complexity" of many infringements of competition law and the practical challenges for claimants to prove such infringements. In her view, under the principle of effectiveness, a final NCA decision must be treated as indicia of the infringement, creating a refutable presumption (prima facie evidence). ${ }^{12} \mathrm{I}$ also believe this to be the correct interpretation of EU Law, in line with the solution adopted in the Directive and with the position of the EFTA Court, ${ }^{13}$ and it has a parallel in the case-law on the effects of commitment decisions (see below).

So far, there is no case-law precedent explicitly discussing the binding effect of decisions of NCAs of other MS. Arguably, the ratio followed by the EFTA Court and by AG Kokott would apply equally thereto. Indeed, nothing in that ratio is specific to decisions adopted within the same MS or dependent upon the decision being adopted by the MS' own NCA.

I am also unaware of any precedents relating to the legal effects of decisions of NCAs of third countries (e.g., if a claim is litigated in a EU MS court, relating to an infringement of US Antitrust Law), but it seems that any such effect would be governed exclusively by national law (since such decisions could never relate to Articles 101 or 102 TFEU). ${ }^{14}$ This issue was unaffected by the Damages Directive.

\footnotetext{
${ }^{10}$ See, e.g., Judgment of 18 December 2014, CA Consumer Finance SA v. Ingrid Bakkaus and Others, Case C-449/13 EU:C:2014:2464, paragraphs 27 et seq.

${ }^{11}$ Judgment of 28 March 2019, Cogeco Communications Inc v. Sport TV Portugal SA and Others, Case C-637/17,EU:C:2019:263, paragraphs 56-60. This part of the referral was inadmissible, because the res judicata decision in question, as amended by the appeal court, did not identify an infringement of Article 101 TFEU.

${ }^{12}$ AG Kokott's Opinion delivered on 17 January 2019, Cogeco Communications Inc v. Sport TV Portugal SA and Others, C-637/17, EU:C:2019:32, paragraphs 41-42, 92-97 and 103. See also AG Mazák's Opinion delivered on 16 December 2010, Pfleiderer AG v. Bundeskartelamt, C-360/09, EU:C:2010:782, paragraph 41.

${ }^{13}$ EFTA Court Judgment of 30 May 2018, Fjarskipti hf. v. Síminn hf., E-6/17, paragraphs 43-48. This position of the EFTA Court is set out in paragraph 47 , despite the broader phrasing of the conclusion.

${ }^{14}$ Claimants have sometimes produced public enforcement, or even private enforcement, decisions from third countries, applying a provision identical to a provision of EU or national Competition
} 
Prior to the Directive, national rules varied widely between the MS.

Some MS did not deem courts bound, in any way, by infringements declared in a public enforcement decision adopted in their own legal order (e.g., Portugal, ${ }_{15}^{15}$ Sweden). Undertakings sometimes failed to prove antitrust infringements already identified in an NCA decision. ${ }^{16}$

Some went for intermediate solutions. In Lithuania, decisions of the NCA created a refutable presumption of the infringement. ${ }^{17}$ In France, the NCA or review court decision was legally binding only in consumer mass damages follow-on actions. ${ }^{18}$ In Spain, a review court judgment confirming an NCA decision was already binding in follow-on actions, but a non-appealed NCA decision was seemingly not (a matter for debate). ${ }^{19}$ In Italy, the NCA's final decisions created a refutable presumption of the infringement, with some limitations on challenging facts already established therein. ${ }^{20}$

Law, so as to persuade the court to arrive at the same finding. It is, in principle, up to each MS to decide how to treat these foreign decisions.

${ }^{15}$ See, e.g.: Judgment of the Porto Appeal Court of 1 March 2007, Nestlé Portugal v. Café de Palha (529/07-3). Order of the Lisbon Judicial Court of 20 December 2012, NOS v. PT (1774/11.9TVLSB). In Latvia, one court was particularly restrictive, prohibiting a claimant from even invoking and referring to the NCA decision in a follow-on action, but that ruling was overturned - see: Judgment of the Riga Regional Court of 6 December 2010 (case C04293109), followed by judgment of the Latvian Supreme Court of 18 February 2013, described in Julija Jerneva and Inese Druviete, "Latvia", in Implementation of the EU Damages Directive in Central and Eastern European Countries, ed. Anna Piszcz (Warsaw: University of Warsaw Faculty of Management Press, 2017), 173.

${ }^{16}$ See, e.g., for Sweden: Judgment of the Svea Court of Appeal of 29 June 2017, Yarps Network Services AB (i likvidation) v. Telia Company AB (T 2673-16), described in Lars Henriksson, "Sweden", in The EU Antitrust Damages Directive: Transposition in the Member States, org. Barry Rodger, Miguel Sousa Ferro, and Francisco Marcos (Oxford: Oxford University Press, 2018), 358. For Portugal, see NOS v. PT, cit.

${ }^{17}$ See Judgment of the Appeal Court of 26 May 2006, Siailiu tara v. Stumbras (case 2A-41/2006) and Judgment of the Lithuanian Supreme Court of 17 May 2010, Klevo lapas v. Olen Lietuva (case 3K-3-207/2010), as described in Valentinas Mikelènas and Rasa Zaščiurinskaitė, "Lithuania", in Implementation of the EU Damages Directive in Central and Eastern European Countries, ed. Anna Piszcz (Warsaw: University of Warsaw Faculty of Management Press, 2017), 200.

${ }^{18}$ Muriel Chagny, "France", in The EU Antitrust Damages Directive: Transposition in the Member States, org. Barry Rodger, B., Miguel Sousa Ferro, And, M. \& Francisco Marcos (Oxford: Oxford University Press, 2018), 101.

${ }^{19}$ See Judgment of the Spanish Supreme Court of 3 November 2017, Mediapro v. Real Zaragoza (ES:TS:2017:3879).

${ }^{20}$ See, e.g.: Court of Cassation, decision no. 13486, 20 June 2011 and Court of Cassation, decision no. 7039, 9 May 2012. 
Other Member States (e.g., Germany, Hungary, ${ }^{21}$ Slovakia, ${ }^{22}$ Slovenia, ${ }^{23}$ and the United Kingdom ${ }^{24}$ ) treated decisions of their own NCA as creating irrefutable presumptions (at least, in principle). Germany also granted binding effects to decisions of NCAs of other Member States.

It has been argued that, even absent binding legal effects, national courts were generally inclined to identify infringements which had already been identified in a decision of the respective NCA, and that such decisions, de facto, had very strong persuasive force. ${ }^{25}$

\subsection{Following the Damages Directive}

Article 9(1) and (2) (together with Article 2(7) and (10) and recitals 34-36) of the Damages Directive require MS to ensure that res judicata public enforcement decisions, which identify an infringement of Articles 101/102 TFEU: ${ }^{26}$ (a) create an irrefutable presumption of the existence of the infringement in question, when adopted by the respective MS's NCA; (b) is prima facie evidence of the infringement in question, when adopted by another MS's $\mathrm{NCA}^{27}$.

Given the scope of the Directive, and some national case-law, ${ }^{28}$ and notwithstanding the effects of general principles discussed above, it seems these rules are relevant only in actions for damages, not in other follow-on

\footnotetext{
${ }^{21}$ See: Article 88/B(6) of the Hungarian Competition Act, introduced in July 2014 to alter the opposite situation created by a prior court ruling. As explained in Peter Miskolczi Bodnár, "Hungary", in Implementation of the EU Damages Directive in Central and Eastern European Countries, ed. Anna Piszcz (Warsaw: University of Warsaw Faculty of Management Press, 2017), 130 and 148.

${ }^{22}$ Ondrej Blažo, "Slovakia", in Implementation of the EU Damages Directive in Central and Eastern European Countries, ed. Anna Piszcz (Warsaw: University of Warsaw Faculty of Management Press, 2017), 258.

${ }^{23}$ Judgment of the Ljubljana High Court of 21 November 2013, Blitz v. Kolosej, quoted in Ana Vlahek and Podobnik Klemen, "Slovenia", in Implementation of the EU Damages Directive in Central and Eastern European Countries, ed. Anna Piszcz (Warsaw: University of Warsaw Faculty of Management Press, 2017), 288.

${ }^{24}$ Section 58A of the Competition Act 1998.

${ }^{25}$ See, e.g.: Judgment of the Spanish Supreme Court of 3 November 2017, Mediapro v. Real Zaragoza (ES:TS:2017:3879) ("aunque pudiera constituir un instrumento de convicción de gran autoridad"); Chagny, M., "France", 101.

${ }^{26}$ All MS transpositions have extended this legal effect to decisions of their own NCA which exclusively apply national competition law.

${ }^{27}$ Criticising this asymmetry: Andersson, Torbjörn. "The binding effects of decisions and judgments under EU competition law". In EU Competition Litigation: Transposition and First Experiences of the New Regime, edited by Magnus Strand, Vladimir Bastidas, Marios C. Iacovides. England: Hart, 2019.

${ }^{28}$ See: Bucan Gutta, The Enforcement of EU Competition Rules, 138.
} 
actions (e.g., seeking injunction or declaration of nullity). The same is not necessarily true for national transpositions, depending on their scope (e.g., in Portugal, it applies to any follow-on action).

The binding effect applies to the res judicata NCA decision on the infringement: ${ }^{29}$

(i) If it is not appealed within the deadline and becomes final;

(ii) If it is appealed, but not in what concerns the finding of the infringement itself (e.g., only in what concerns the amount of the fine) $;{ }^{30}$ or

(iii) If it is appealed, but not by the undertaking against whom the private enforcement action has been filed (subjective scope of res judicata).

If the NCA decision is appealed (in the relevant part, by the relevant person), the binding decision will be the review court judgment, which may identify the same or a different infringement from the one identified in the NCA decision. This judgment becomes binding:

(i) If it is not appealed within the deadline;

(ii) If it is handed down by a last instance review court; or

(iii) If the judgment is appealed, but not in what concerns the finding of infringement.

Unfortunately, the Directive only includes "ordinary means of appeal" in the concept of review court. ${ }^{31}$ Subject to CJEU interpretation of that concept, this seems to mean a decision may be deemed final, under the Directive, while there is still a chance that it will be overturned (e.g., by a Constitutional Court, ${ }^{32}$ by the ECHR, or in an extraordinary case-law uniformization appeal). ${ }^{33}$ Should national courts stay proceedings in such cases? Are they bound by EU

\footnotetext{
${ }^{29}$ The same is true, mutatis mutandis, for EC decisions.

${ }^{30}$ This interpretation has been explicitly included in the transposition of the Damages Directive in France.

${ }^{31}$ See Article 9(1). Article 2(10) of the Damages Directive.

${ }^{32}$ Judicial review systems vary from MS to MS. In Portugal, for example, if an NCA decision is deemed to have infringed the Constitution by the Constitutional Court, the act is annulled without a further decision by an administrative or judicial authority being required.

${ }^{33}$ See, for England \& Wales: Enron Coal Services Ltd (in Liquidation) v. English, Welsh and Scottish Railway Ltd [2011] EWCA Civ 2. Similar issues arise about extraordinary cases in which a res judicata judgment may be amended or revoked - for Portugal, see Article 80 of the General Misdemeanour Regime, and Articles 449 et seq. of the Code of Criminal Procedure.
} 
Law to decide in accordance with a decision which may still be annulled? Are they still bound even if it is annulled in an extraordinary means of appeal? The Directive suggests so, but that would be a strange state of affairs.

As for the binding effect of decisions of NCAs of other MS, the expression prima facie evidence is typically understood as meaning evidence which is not conclusive (i.e., not an irrefutable presumption), but which stands until contradictory evidence is presented to the court, effectively implying a (at least initial) reversal of the burden of proof. Thus, both prior to, and after, the Damages Directive and its transposition, decisions of NCAs of other Member States create a juris tantum (refutable) presumption. Some MS have slightly changed the language in their transposition to make this clearer. ${ }^{34}$ No MS, other than Germany, went further and gave decisions of other MS the effect of irrefutable presumptions.

The differentiation of the legal value of administrative and judicial decisions of other MS (not initially proposed by the Commission) seems to be rooted in a distrust by some MS and some MEPs in the compliance with the rule of law and judiciary independence in other MS. ${ }^{35}$ These concerns are unlikely to disappear despite the ECN+ Directive ${ }^{36}$. While the basis for these concerns is well known and not unreasonable, it is difficult to reconcile them with a legal order which decentralises the enforcement of Articles 101 and 102 TFEU and trusts MS to apply those rules in accordance with EU Law and fundamental rights, and which has harmonised Private International Law rules in a way that often allows injured parties to sue in a MS different from the one where the public enforcement decision was adopted. ${ }^{37}$

To date, there are very few known instances where a public enforcement decision of one MS has been invoked before courts of another MS in a follow-on action. ${ }^{38}$

\footnotetext{
${ }^{34}$ See, e.g., for Portugal, Article 7(2) of Law 23/2018 ("presunção ilidível”).

${ }^{35}$ See Maria José Costeira, "A transposição da Diretiva Private Enforcement: Perspetiva crítica”, UNIO - EU Law Journal 3, no. 2 (2017): 175. The European Parliament also strangely questioned whether the EU was competent do adopt such a rule - see European Parliament, Resolution of 26 March 2009 on the White Paper on damages actions for breach of the EC antitrust rules (2008/2154(INI)), https:// eur-lex.europa.eu/legal-content/EN/TXT/?uri=CELEX\%3A52009IP0187, paragraphs 2 and 6.

${ }^{36}$ Directive 2019/1 of the European Parliament and of the Council, of 11 December 2018 (OJ L $11 / 3,14 / 01 / 2019)$.

${ }^{37}$ On enforcement of judicial decisions of other MS in this context, see AG Jääskinen's Opinion delivered on 11 December 2014, CDC Hydrogen Peroxide v. Evonik Degussa GmbH and Others, C-352/13, ECLI:EU:C:2014:2443, paragraph 116 and footnote 132.

${ }^{38}$ See the flyLAL case (between Lithuania and Latvia), still ongoing, which led to Case C-302/13 flyLAL (I) EU:C:2014:2319, and to Case C-27/17 flyLAL (II) EU:C:2018:533; and a case involving
} 
EU Law does not award binding legal effects to private enforcement judg$\underline{\text { ments }}$ in subsequent cases relating to the same infringement. However, the Romanian transposition may allow for an interpretation that such judgments also create an irrefutable presumption. ${ }^{39}$

Issues such as the scope of the burden of allegation of facts by the party invoking the binding effect of the public enforcement decision, or the moment until when a Commission or NCA decision may be added to the case file, ${ }^{40}$ are governed by national law, subject to equivalence and effectiveness, and may lead to heterogeneous solutions throughout the EU.

As Article 9(3) (and recital 35) of the Damages Directive reminds us, national courts are empowered (and may be obliged) to use the referral mechanism to ask the CJEU for clarifications about the precise extent to which they are bound by a public enforcement decision or any other specific doubt which may arise.

\section{Material scope of the binding effect}

Res judicata (EC or own NCA) decisions establish the existence of the infringement. The party invoking the infringement benefits from an irrefutable presumption (juris et de jure) of the existence of that infringement, as declared in the decision/judgment, simply by producing it or having it produced. This effect is limited to the finding that a "prohibited agreement or practice exists", while "the existence of loss and of a direct causal link (...) remains, by contrast, a matter to be assessed by the national court" ${ }^{41}$ This must also apply to national decisions. ${ }^{42}$

Greece and the Netherlands - Macedonian Thrace Brewery v. Heineken et al., filed on 23 February 2017 before the District Court Amsterdam, C/ 13/ 626096, HA ZA 17- 321.

${ }^{39}$ Article 9(1) of Emergency Ordinance 39/2017. See: Valentin Mircea, "Romania", in Implementation of the EU Damages Directive in Central and Eastern European Countries, ed. Anna Piszcz (Warsaw: University of Warsaw Faculty of Management Press, 2017), 244.

${ }^{40}$ In this regard, for Portugal, see: Judgment of the Porto Appeal Court of 1 March 2007, Nestlé Portugal v. Café de Palha (529/07-3).

${ }^{41}$ Judgment of 6 November 2012, Europese Gemeenschap v. Otis NV and Others, Case C-199/11, EU:C:2012:684, paragraphs 65-66. See also AG Cruz Villalón's Opinion delivered on 26 June 2012, Europese Gemeenschap v. Otis NV and Others, C-199/11, EU:C:2012:388, paragraph 54.

${ }^{42}$ In this sense, see, e.g.: Enron Coal Services Ltd (in Liquidation) v. English, Welsh and Scottish Railway Ltd [2009] CAT 7. Barry Rodger, "United Kingdom", in The EU Antitrust Damages Directive: Transposition in the Member States, org. Barry Rodger, Miguel Sousa Ferro, and Francisco Marcos (Oxford: Oxford University Press, 2018), 378. Paola Piroddi, "Damages actions for infringement of competition rules and the right to a fair trial under article 6(1) ECHR", in Private Enforcement of Competition Law, Luis Antonio Velasco San Pedro et al. (Valladolid: Lex Nova, 2011), 445. 
In other words, the claimant must still prove that there were damages (unless it is a cartel and the presumption of damages applies), that the damages were caused by that infringement, and quantify the damages to the extent feasible. In the past, claimants have often failed to obtain damages even in cases in which the infringement was already proven. ${ }^{43}$

The scope of the binding effect extends, according to the Directive's recital 34, reproduced in several MS transpositions, ${ }^{44}$ to the material, personal, temporal and territorial scope of the infringement identified in the decision. But this is of little help. As noted in the UK, national courts have had "difficulties in determining the scope of the effect of a prior binding infringement decision". ${ }^{45}$ Courts have disagreed about which infringement was identified. ${ }^{46}$

To understand the practical difficulties, one must first realise that, in reality, EC/NCA and review court decisions often do not provide a clear description of what the infringement was. From the perspective of a potential injured party trying to understand whether the infringement in question affected it, the operative part will almost always be insufficient to understand what, exactly, was the infringement. It is one thing to know that there were, e.g., price fixing agreements in a given market over a given period of time. But this may not be enough to know what exactly was agreed, which products and sales were specifically affected and how, if the duration of the infringement is different from the timeframe of the sales it affected, ${ }^{47}$ etc. This may not even be perceptible from the full text of the (public or even confidential) decision. This problem has been

\footnotetext{
${ }^{43}$ As noted in Richard Whish, "Damages actions in the Courts of England and Wales", in Private Enforcement of Competition Law, Luis Antonio Velasco San Pedro et al. (Valladolid: Lex Nova, 2011), 158. See, e.g., for Poland: Judgment of the Krakow Court of Appeal of 10 January 2014 (I Aca 1322/13), and Judgment of the Lublin Regional Court of 4 July 2014 (I C 759/08), both described in Maciej Bernatt \& Maciej Gac., "Poland", in The EU Antitrust Damages Directive: Transposition in the Member States, org. Barry Rodger, Miguel Sousa Ferro, and Francisco Marcos (Oxford: Oxford University Press, 2018), 290.

${ }^{44}$ See, e.g., for Portugal, Article 7(1), (2) and (3) of Law 23/2018.

${ }^{45}$ Rodger, "United Kingdom", 378. See, as precedents from England \& Wales: Enron Coal Services Ltd (in Liquidation) v. English, Welsh and Scottish Railway Ltd [2009] CAT 7 and on appeal to the Court of Appeal, [2009] EWCA Civ 647, and also the subsequent Court of Appeal ruling in the same case [2011] EWCA Civ 2. Emerson Electric Co v. Morgan Crucible Co PLc [2011] CAT 4. Deans Foods Ltd v. Roche Products Ltd, Case no. 1029/5/7/04.

${ }^{46}$ Enron Coal Services Ltd (in Liquidation) v. English, Welsh and Scottish Railway Ltd [2009] CAT 7, [2009] EWCA Civ 647 and [2011] EWCA Civ 2.

${ }^{47}$ While the issue may not arise for exchanges falling within the middle of the period identified in the public enforcement decision, there may be substantial discussions about whether the declared
} 
exacerbated by authorities' willingness to negotiate the content of a decision in exchange for a settlement with the undertakings under investigation, sometimes making decisions so vague as to be useless for follow-on claims for damages, ${ }^{48}$ at least by themselves (without some clarification or access to the case file). That being said, the declared infringement must be understood to be the one identified in the operative part of the decision, even if it is necessary to resort to the body of the decision, and to other documents, to properly interpret the operative part. This is also clear in the case of review court judgments, whose operative part may say nothing more than "the appeal is dismissed" or "partly dismissed". ${ }^{9}$

Public enforcers sometimes use the rendering of private enforcement actions as a bargaining chip to achieve settlements and save time and resources. While this may be legitimate, the EC/NCAs should, perhaps, also keep in mind that they have a duty to cooperate with national courts and are subject to the principle of effectiveness. Both these principles may arguably be interpreted as requiring them not to deprive Article 16(1) of Regulation (EC) 1/2003 and Article 9(1) of the Damages Directive of their effet utile by making their decisions so succinct that it is impossible or excessively difficult to identify the infringement.

In a worst case scenario of incompleteness or obscurity of the decision, it must be possible for a national court to ask the EC for clarifications which will allow it to understand which infringement was declared, and whether the specific exchanges in question in the private enforcement action before it fall within that infringement. The same is probably true of the duty of cooperation of competition authorities with national courts in each MS legal order.

\footnotetext{
infringement encompasses exchanges immediately after the initial date (or only sometime after), and whether it encompasses exchanges occurred sometime after the final date.

${ }^{48}$ See, e.g.: David Ashton, Competition Damages Actions in the EU: Law and Practice, $2^{\text {nd }}$ edition (United Kingdom: Edward Elgar, 2018), 87; Damien Geradinand, Evi Mattioli, “The transactionalization of EU competition law: A positive development?” (September 20, 2017), TILEC Discussion Papers 2017, no. DP 2017-035, https://www.tilburguniversity.edu/research/institutesand-research-groups/tilec/research/discussion-papers/2017.

${ }^{49}$ Certain legal orders may provide additional difficulties in this regard - see, e.g.: Mary Catherine Lucey, "Ireland", in The EU Antitrust Damages Directive: Transposition in the Member States, org. Barry Rodger, Miguel Sousa Ferro, and Francisco Marcos (Oxford: Oxford University Press, 2018), 193, Barry Doherty and Anne Fitzpatrick, "Courage to change? The rocky road to Directive 2014/104/ EU and the future of private competition law enforcement in Ireland", Irish Journal of European Law 18, no. 2 (2015): 15.
} 
While it will almost always be necessary to resort to the body of the decision/judgment, only the statements included therein which positively define the scope of the declared infringement are binding on national courts (limited to the finding that a "prohibited agreement or practice exists" $\left.{ }^{\prime \prime}\right)$.

Thus, instrumental "facts" affirmed in the decision are not, in themselves, binding, unless they are an integral and indispensable part of the declaration of infringement. If, for example, in a decision identifying a price-fixing cartel (object restriction), the Commission mentions that the cartel led to a price increase, this is, in principle, not an integral part of the finding of infringement and is not binding. Some NCAs may need to discuss the effects of a given practice (even an object restriction) so as to assess its gravity and justify the amount of the fine, but any position taken in this context is not relevant for the finding of the infringement in itself.

Differently, a declaration of an effects infringement necessarily includes a description of the effects on the market, which are indissociable from the declaration of the infringement and are, thus, binding. An identification of an abuse of dominance is indissociable from a given market definition, which must also be binding in a follow-on action. A national court judgment cannot, without incurring in internal contradiction, be bound by those findings of fact in what concerns the existence of the infringement, but disregard them for other purposes (e.g., when assessing causality or damages).

Some authors have suggested that this debate may also arise around the finding of fault. But such positions may rest on the misconception that the requirement of fault in damages actions based on infringements of Articles $101 / 102$ TFEU is governed by national law, whereas, as I understand the case-law, it is governed by EU Law. Following the Skanska ruling, ${ }^{51}$ and its harmonisation of the solutions for public and private enforcement, it seems expectable that the CJEU will clarify that EU Competition Law does not require the demonstration of fault as a basis for liability for damages in these actions. This is an issue of the interpretation of Articles 101/102 TFEU and general principles of EU Law. It is thus inconsequential to argue that the Directive did not harmonise this aspect (or to point out its recital

\footnotetext{
${ }^{50}$ Judgment of 6 November 2012, Europese Gemeenschap v. Otis NV and Others, Case C-199/11, EU:C:2012:684, paragraph 65.

${ }^{51}$ Judgment of 14 March 2019, Cantaan kaupunki v. Skanska Industrial Solutions Oy and Others, C-724/17, EU:C:2019:204.
} 
11). Precedents in other areas of EU Law clearly establish that if a right already derives from the Treaty (the requirement of fault is a fundamental component in the identification of a right to damages arising from Articles 101/102 TFEU), a harmonising Directive cannot in itself limit that right. ${ }^{52}$

As for actions based exclusively on infringements of national competition law, if the NCA decision is required by national law to establish some degree of fault, this finding must also be deemed binding in a follow-on action. $^{53}$

Whereas a finding of an infringement of Article 102 incorporates the assessment of procompetitive effects (economic balance test), a declaration of an infringement of Article 101(1) need not, necessarily, imply a declaration that the requisites of Article 101(3) are not met. Often, competition authorities simply affirm that infringers have not met their burden of proof that the requisites are met. If so, the legally binding effect is limited to the declaration of the infringement of Article 101(1). If so, it is still, in principle, open to the undertakings in question to try to prove, in the follow-on action, that the requisites of 101(3) were met, as long as this is done by putting forward novel evidence and/or arguments which were not already considered in the res judicata public enforcement decision.

A negative declaration, saying there is no infringement because one or more of the requisites of the prohibition is not met is not binding under Article 9(1) of the Directive. At least two Member States - Hungary and Poland - amended their national laws specifically to ensure this outcome. But actually, when it comes to infringements of Article 101 or 102 TFEU, national public enforcement proceedings may not lead to negative declarations. ${ }^{54}$ So this issue can only be raised about negative declarations relating to national competition law.

\footnotetext{
${ }^{52}$ See, e.g., in the realm of free movement of workers, the case-law on the concept of worker Judgment of 19 June 2014, Jessy Saint Prix v. Secretary of State for Work and Pensions, C-507/12, EU:C:2014:2007 (e.g., paragraph 32).

${ }^{53}$ In this sense, see: Henriksson, "Sweden", 358; and Jerneva and Druviete, "Latvia", 174. In Germany, there is a precedent which adopts this interpretation - see: Landgericht Köln, 88 O 1/11, 17 January 2013 (CR 2013, 297-302), paragraphs 184 et seq.; Oberlandesgericht Karlsruhe, 6 U 52/12 Kart, 31 July 2013 (IBRRS 2013, $5084=$ NZKart 2014, 366), paragraphs 46-47, as described in Ashton, Competition Damages Actions in the EU, $\$ 2.70$.

${ }^{54}$ Judgment of 3 May 2011, Prezes Urzędu Ochrony Konkurencji i Konsumentów v. Tele2 Polska sp. $z$ o.o., devenue Netia SA, C-375/09, EU:C:2011:270, maxime paragraphs 21-30; Judgment of 25 November 2014, Orange v. European Commission, T-402/13, EU:T:2014:991, paragraph 30.
} 


\section{Subjective scope of the binding effect}

The binding effect of EU decisions (EC decisions and GCEU/CJEU judgments) is governed by the Masterfoods $s^{55}$ case-law and by Article 16(1) of Regulation (EC) $1 / 2003$. Neither mention subjective scope. Understandably so. As noted above, this binding effect is not rooted in effectiveness or reasons of procedural economy, it is rooted in the separation of powers between EU/MS, in the exclusive powers of the EC, the primacy of EU Law, and the need to ensure the uniform application of EU Competition Law.

Accordingly, the declaration of the infringement by the Commission (or confirmed by the Court) must be binding on national courts (irrefutable presumption) regardless of the parties to the dispute, and of whether or not they were addressees of the EU decision (erga omnes effect). Even in disputes between third parties, national courts cannot conclude that an infringement already declared in the exercise of exclusive EU powers did not occur. This interpretation is harmonious with the Court's case-law on commitment decisions and their impact on the rights of third parties (see below).

However, this has not been the interpretation adopted by some national courts. ${ }^{56}$

As for national decisions (NCAs and review courts), we must distinguish the legal obligations which derive from Articles 101/102 TFEU, together with general principles of EU Law, from the legal obligations which derive from the Damages Directive and its transpositions.

Prior to the Directive, an NCA decision had to be treated as prima facie evidence in order to ensure the effectiveness of the right to damages deriving from the Treaty. This reasoning does not depend on the identity of the addressees of the decision, nor of whether they took part in the public enforcement decision and had the opportunity to defend themselves in that context. The justification for granting the decision some legal effects is based on whether it is impossible or excessively difficult to prove the infringement in the absence of this prima facie evidence. Accordingly, it is this test which must be applied, while also applying the same test to

\footnotetext{
${ }_{55}^{55}$ Judgment of 14 December 2000, Masterfoods Ltd v. HB Ice Cream Ltd, C-344/98, EU:C:2000:689.

${ }^{56} \mathrm{~A}$ UK court seemingly interpreted the Law as meaning that only the legal persons who were the addressees of an EC decision were bound by that decision in a follow-on action - see: Emerson Electric Co v. Morgan Crucible Co plc [2011] CAT 4, as described in Rodger, "United Kingdom", 378. In Portugal, a national court agreed with the EC that a UEFA Regulation was invalid, but did not seem to consider itself bound by the previous declaration of that invalidity by the EC - see judgment of the Lisbon Appeal Court of 10 November 2009, VSC and FPF v. RTP (4292/1999.L1).
} 
the third party (which, unlike the infringing undertaking, may not have access to evidence necessary to prove the absence of the infringement). Indeed, such an effect would not be admissible if it made it impossible or excessively difficult for the third party to disprove the infringement. This should be assessed on a case-by-case basis.

Under the Directive ${ }^{57}$ and its transpositions, the infringement is irrefutably established for the purposes of actions for damages. Again, the ratio legis is the protection of the effectiveness of the right to damages and the promotion of legal certainty and uniform application of EU Law. While some may argue that the reference to the "personal" scope, in recital 34, should be understood as referring to the legal entity identified in the NCA decision, Competition Law is not formalistic in that way. When identifying the "person" referred to, one must consider that Competition Law prohibits infringements by "undertakings", defined as economic units. An NCA is free to decide which legal entity within the "undertaking" it imposes the fine on, but, in the eyes of Competition Law, the infringement was carried out by the "undertaking". 58

This means that, arguably, the binding effect of a decision addressed to a subsidiary may also be invoked against its parent company in a followon action. While the Court has not specifically clarified this issue, it has provided the basis for the answer in Skanska, ${ }^{59}$ when it stated that all clarifications of liability in public enforcement apply to private enforcement, and that EU Competition Law is a lex specialis which assigns liability for infringements to the "undertaking", defined as an economic unit.

The argument that this infringes fundamental rights, as the parent company was not given the opportunity to defend itself, is formalistic and erroneous. The very concept of "undertaking" rests on the determination that the parent company is able to exercise control over the subsidiary, and so it had the ability to direct it in its defence against the public enforcement decision. Furthermore, the argument may be turned on its head. Even if a parent company is not an addressee of an EC or NCA decision, since the decision can have legal effects on it in follow-on actions, the requisites

\footnotetext{
${ }^{57}$ Article 9(1) and (2) and recital 34.

${ }^{58}$ There is always the right of challenging the inclusion of a given legal person within the "undertaking".

${ }^{59}$ Judgment of 14 March 2019, Vantaan kaupunki v. Skanska Industrial Solutions Oy and Others, C-724/17, EU:C:2019:204. See Christian Kersting, "Private law liability of the undertaking pursuant to Art. 101 TFEU”, Wirtschaft und Wettbewerb (2019), 290, https://ssrn.com/abstract=3439973.
} 
of Article 263(\$4) TFEU, as clarified in the Plaumann case-law ${ }^{60}$ (and the equivalent requisites of, likely, all MS legal orders), are met. It is directly and individually affected and has the right to appeal the decision.

On the flipside of the coin, for the purposes of follow-on actions, the effects of an appeal against an EC/NCA decision, by any legal entity within an undertaking, must extend to all legal entities within the undertaking, and even to its managers and directors. ${ }^{61}$

As it has been accepted that this binding effect is needed to ensure the effectiveness of the right to damages, concluding that only the legal persons who were addressees of the decision are bound by the irrefutable presumption of the infringement (and not the whole undertaking of which they are a part) could often jeopardise that effectiveness, allowing undertakings to escape liability simply through corporate restructuring (as demonstrated in Skanska), or through depletion of assets. It would also create a heterogeneous solution in relation to the binding effects of infringements declared by the EC.

I believe the same reasoning requires the binding effect to extend to horizontal or vertical descending liability (liability of subsidiaries for infringements carried out by the parent company or other subsidiaries), ${ }^{62}$ but this is an issue which has not been clearly settled in the case-law, even in the sphere of public enforcement. There are recent precedents in Spain, namely from the commercial court of Valencia, in the trucks cartel, which have declared the binding effect for the subsidiary of the finding of infringement in the decision addressed to the parent company.

\footnotetext{
${ }^{60}$ Judgment of 15 July 1963, Plaumann \& Co. v. Commission of the European Economic Community, 25/62, EU:C:1963:17. In this regard, see, by analogy, the right of appeal relating to commitment decisions recognised to third parties in Judgment of 11 July 2007, Alrosa Company Ltd v. Commission of the European Communities, T-170/06, EU:T:2007:220, and Judgment of 12 December 2018, Groupe Canal + European Commission, T-873/16, EU:T:2018:904.

${ }^{61}$ Managers and directors of undertakings are not subject to fines by the European Commission, but they are subject to fines imposed by the NCAs of some of the Member States (e.g., Portugal and Spain). In these countries, theoretically, managers and directors may also be defendants in follow-on claims for damages and may also be subject to the irrefutable presumption created by the declaration of the infringement in the NCA decision (but only if they were addressees of the decision, since they are not a constituent part of the "undertaking"). For further on this issue, see Kersting, "Private law liability", and, specifically for Portugal: Maria Elisabete Ramos, "Situação do 'private enforcement' da concorrência em Portugal”, Revista de Concorrência e Regulação, no. 27-28 (2016): 27; Jorge Manuel Coutinho de Abreu, Responsabilidade Civil dos Administradores de Sociedades, 2. a edição (Coimbra: Almedina, 2010), 83 et ss.

${ }^{62}$ See Christian Kersting, "Liability of sister companies and subsidiaries in European competition law", Zeitschrift für das gesamte Handelsrecht und Wirtschaftsrecht 182, no. 8 (2018).
} 
Also thanks to Skanska, we already know that the binding effect of an $\mathrm{EC} / \mathrm{NCA}$ decision extends to the legal or purely economic successor of the infringing undertaking, making this a hot topic in mergers and acquisitions. Again, a different conclusion would make it easy for companies to deprive the right to damages of its effet utile.

The subjective scope is also temporal, since decisions often distinguish the period during which the various undertakings participated in the infringement in question.

In the case of decisions declaring a single and continuous infringement, we can extract from the general principle affirmed in Skanska that cartel members are liable for the various components of that infringement, even if they did not participate in all of them, because they contributed to the common objectives of the infringement and were aware of, or could reasonably have foreseen, the existence of the overall infringement (potentially, relating to sales of products the undertaking does not supply, in territories where it had no sales, etc.). ${ }^{63}$

Often, in cartel cases, some undertakings appeal the EC/NCA decision and others do not (namely due to leniency or settlements). Considering the joint and several liability of cartel participants, injured parties are faced with the option of suing only those against whom the decision is already final, or of suing all of them jointly and litigating a case in which it must prove the infringement for some, but not for others (or a staying of proceedings would be justified for some, but not for others). This is bound to raise complex questions. ${ }^{64}$

If, for example, an undertaking which settled is sued by a customer of one of the other cartel members, it is bound by the declaration of infringement. However, the other cartel member is not, and the decision could even be annulled by a review court as far as it is concerned. If so, the cartel member who paid the damages under joint and several liability would only be able to recover that compensation from the undertaking which succeeded in having the decision annulled if it proved that it did indeed take part in an unlawful cartel. In the same example, would the sued cartel

\footnotetext{
${ }^{63}$ See, e.g.: Michael J. Frese, "Civil liability for single and continuous infringements", World Competition 41, no. 2 (2018): 179.

${ }^{64}$ See, e.g.: Anna Piszcz, "Implementing the rules of the Damages Directive on joint and several liability: The SME derogation", EU Competition Litigation: Transposition and First Experiences of the New Regime, ed. Magnus Strand, Vladimir Bastidas, Marios C. Iacovides (England: Hart, 2019).
} 
member be allowed to call the other cartel members to the action, even though this would effectively mean forcing the injured party to litigate against all of them? As the Directive is seemingly silent on these issues, the answer to these questions must be found in national procedural law, subject to the limits of equivalence and effectiveness.

\section{Temporal scope of the binding effect}

Beyond the temporal scope of the finding of infringement in itself, issues may arise with the temporal scope of the binding effect, because of succession of laws. The question does not arise in relation to the irrefutable presumption created by EC decisions, or the value of prima facie evidence of NCA decisions, since both derive from the Treaty and general principles of EU Law, as clarified by Court.

The question arises, however, whether NCA decisions adopted prior to the transposition of the Directive in the respective MS are binding on a national court faced with a follow-on action, if it is deciding after the transposition is in force. The answer depends on whether Article 9(1) is deemed a procedural or substantive provision. In the first case, it should be applied to pending cases. In Cogeco, AG Kokott stated it was a substantive provision, ${ }^{65}$ but provided no justification. This position seems to imply that all rules relating to the probative value of documents are substantive, which, as a matter of EU Law, seems rather doubtful. It is not up to the MS to decide this issue based exclusively on their own national law, because they are required to comply with their obligation under Articles 9(1) and 22 of the Directive and to interpret national provisions in conformity with the Directive, to the extent possible.

\section{Obligations of national courts relating to non-final infringement decisions}

A national court faced with a follow-on action to an EC infringement decision which is not yet final is not entirely free to decide what to do. ${ }^{66}$ The obligation to avoid contradiction with EC decisions exists even if the decision is not yet final (e.g., appealed to the GCEU), and even if its application has been suspended. This is so because acts of EU Institutions "are in

\footnotetext{
${ }^{65}$ AG Kokott's Opinion delivered on 17 January 2019, Cogeco Communications Inc v. Sport TV Portugal SA and Others, C-637/17, EU:C:2019:32, paragraph 62.

${ }^{66}$ It is not entirely compatible with EU Law for the transposition of the Damages Directive to say that courts "may" (an option) stay proceedings - see, e.g., for Portugal, Article 7(4) of Law 23/2018.
} 
principle presumed to be lawful until such time as they are annulled or withdrawn", and because the national court cannot control the validity of those acts. In these cases, the court has only two options: (i) suspend proceedings to await the outcome of the annulment action; or (ii) suspend proceedings and refer the issue of the validity of the decision to the CJEU. ${ }^{67}$ The national court should assess "whether it is necessary to order interim measures in order to safeguard the interests of the parties pending final judgment" ${ }^{\prime 68}$ (the effectiveness of rights conferred by the EU legal order requiring such interim measures to be issued when this is the case).

The same approach may be used for non-final NCA decisions, since national courts must interpret their national transposition in conformity with the Directive, ensuring that the effet utile of Article 9(1)'s obligation is protected.

\section{Obligations of national courts relating to ongoing investigations}

Under Article 16(1) of Regulation 1/2003, if the Commission is investigating an infringement, national courts must "avoid giving decisions which would conflict with" the potential decision, and, for that purpose, "may assess whether it is necessary to stay its proceedings". There is no obligation to stay proceeding to wait for the decision, but the duty of sincere cooperation suggests this may be the ideal option (to be exercised ex officio) ${ }^{69}$ National courts can request information from the Commission about ongoing investigations. ${ }^{70}$

As a matter of EU Law, there is no corresponding obligation for ongoing investigations before NCAs. However, such an obligation may derive from national law. ${ }^{71}$

\footnotetext{
${ }^{67}$ Judgment of 14 December 2000, Masterfoods Ltd v. HB Ice Cream Ltd, C-344/98, EU:C:2000:689, paragraphs 53-57 and 59. See also AG Cosmas' Opinion delivered on 16 May 2000, Masterfoods Ltd v. HB Ice Cream Ltd, C-344/98, EU:C:2000:249, paragraphs 38-48 and 50-55.

${ }^{68}$ Judgment of 14 December 2000, Masterfoods Ltd v. HB Ice Cream Ltd, C-344/98, EU:C:2000:689, paragraph 58. See also: Judgment of 12 December 2018, Groupe Canal + v. European Commission, T-873/16, EU:T:2018:904, paragraphs 104 and 116.

${ }^{69}$ This has been specifically foreseen, e.g., in Portugal (see Article 7(4) of Law 23/2018 and Public Consultation Report, paragraph 36).

${ }^{70}$ See European Commission, Commission Notice on the cooperation between the Commission and the courts of the EU MS in application of Arts 81 and 82 EC (OJ C 101/54, 27/04/2004, as revised in OJ C 256/5, 05/08/2015), https://eur-lex.europa.eu/legal-content/EN/ALL/?uri=CELEX\%3A5200 4XC0427\%2803\%29, paragraphs 21 and 22.

${ }^{71}$ In Portugal, this scenario has been foreseen in the transposition of the Damages Directives, which allows courts discretion in deciding whether to suspend proceedings (Article 7(4) of Law
} 


\section{State aid decisions}

The Court has already provided clarifications on the effects of State aid decisions in the context of private enforcement actions. When a national court is asked by a competitor for damages and/or to order the recovery of unlawfully granted, non-notified State aid (and to prevent ongoing aid), there are two possible scenarios: ${ }^{72}$

a) if the EC has not initiated a formal examination procedure, the national court must, by itself, decide if the measure constitutes State aid and should have been notified;

b) if the Commission has initiated the formal examination procedure under Article 108(2) TFEU, its preliminary finding that the measure constitutes State aid does have legal effects: the national court is required to adopt all necessary measures to draw the appropriate conclusions from an infringement of the obligation to suspend implementation. The national court may decide to suspend implementation of the measure and order recovery of payments already made. It should order provisional measures needed to safeguard the interests of the parties concerned and the effectiveness of the Commission's decision. ${ }^{73}$

23/2018). The fact that a public enforcement investigation is pending before the NCA concerning the same infringement does not create a situation of lis pendens, nor any other impediment to the exercise of the court's powers, including the adoption of provisional measures (Judgment of the Lisbon Court of Appeal of 20 May 2010, [B] v. [Banco...] e [S] (1/10.0TVLSB.L1-8). With a seemingly similar solution, see: Judgment of the Prague Higher Court of 16 August 2012 (case 222/2012); and Judgment of the Prague Higher Court of 4 June 2013 (case 126/2013), quoted in Michal Petr, "Czech Republic", in Implementation of the EU Damages Directive in Central and Eastern European Countries, ed. Anna Piszcz, (Warsaw: University of Warsaw Faculty of Management Press, 2017), 105. In Hungary, civil courts were (and continue to be) required to suspend the procedure and wait for the decision of the Hungarian NCA - see Bodnár, "Hungary", 130.

${ }^{72}$ It goes without saying that a national court, faced with a private enforcement action relating to (alleged) State aid measures, is absolutely bound by a decision of the EC declaring that the measure in question does not constitute State aid, or that it is compatible with the TFEU.

${ }^{73}$ Judgment of 21 November 2013, Deutsche Lufthansa AG v. Flughafen Frankfurt-Hahn GmbH, C-284/12, EU:C:2013:755, paragraphs 31-45. Order of 4 April 2014, Flughafen Lübeck GmbH v. Air Berlin plc \& Co. Luftverkehrs KG, C-27/13 EU:C:2014:240, paragraphs 18-27. See: Viktor Kreuschitz and Nuria Bermejo, "The role of national courts in the enforcement of the European state aid rules", in EU Competition and State Aid Rules: Public and Private Enforcement, eds. Vesna Tomljenovic, et al. (Berlin: Springer, 2017), 221. 
The national court may not decline to decide or order measures before the EC adopts its decision on the State aid measure in question, because this would have the same effect as rejecting the application and would deprive Article 108(3) of its effectiveness. ${ }^{74}$

\section{Merger control decisions}

There has, seemingly, not yet been a discussion, at EU or national level, of the binding effect of EC merger control decisions in follow-on actions before national courts (based, e.g., on damages caused by gun-jumping). No binding effect is imposed by the Directive for follow-on actions relating to EC/NCA merger control decisions. Nor has, seemingly, any Member State taken this extra step. That being said, it seems reasonable to assume that the Court's case-law on the effects of the Commission's decisions applying Articles 101/102 and State aid rules should be applied by analogy to merger control.

\section{Commitment decisions}

Commitment decisions are adopted by the EC under Article 9 of Regulation (EC) $1 / 2003,{ }^{75}$ and by NCAs under their respective national laws. Such decisions do not certify compliance (they do not "legalise" past behaviour), so national courts are free to conclude that the practice in question infringed EU Law. ${ }^{76}$

An EC commitment decision is preceded by a preliminary assessment where "competition concerns" (potential infringements) are identified, but it does not decisively find that there was, or still is, an infringement of Article 101 or 102 TFEU. ${ }^{77}$ The same is true for commitment decisions

\footnotetext{
${ }^{74}$ Order of 4 April 2014, Flughafen Lübeck GmbH v. Air Berlin plc \& Co. Luftverkehrs KG, C-27/13 EU:C:2014:240, paragraphs 28-32.

${ }^{75}$ See also recitals 13 and 22 of Regulation (EC) 1/2003. See also: Judgment of 12 December 2018, Groupe Canal + v. European Commission, T-873/16, EU:T:2018:904, paragraphs 63, 89 and 99; Judgment of 11 July 2007, Alrosa Company Ltd v. Commission of the European Communities, T-170/06, EU:T:2007:220, paragraphs 89-91; Judgment of 29 June 2010, European Commission v. Alrosa Company Ltd, C-441/07, EU:C:2010:377, paragraphs 34-35.

${ }^{76}$ Judgment of 23 November 2017, Gasorba SL and Others v. Repsol Comercial de Productos Petroliferos SA, C-547/16, EU:C:2017:891, paragraphs 25-28. AG Kokott's Opinion delivered on 14 September 2017, Gasorba SL and Others v. Repsol Comercial de Productos Petroliferos SA, C-547/16, paragraph 39.

${ }^{77}$ Judgment of 23 November 2017, Gasorba SL and Others v. Repsol Comercial de Productos Petroliferos SA, C-547/16, EU:C:2017:891, paragraphs 25-26. Judgment of 11 July 2007, Alrosa Company Ltd v. Commission of the European Communities, T-170/06, EU:T:2007:220, para-
} 
adopted by NCAs. ${ }^{78}$ One could, thus, expect such decisions to have no legal effects whatsoever in private enforcement actions relating to the same practices. But not so. According to the CJEU, at least when it comes to EC commitment decisions, they have legally binding effects which may be used for the benefit of the claimant or of the defendant.

The Court's position in this regard rests on its case-law on the judicial review of commitment decisions and its implications for the content, nature and reasoning of the "preliminary assessment". The legitimacy of the commitment decision itself depends on the existence of a duly reasoned identification (in a preliminary assessment) of anticompetitive practices justifying its adoption, allowing the Court to control the reasoning for the existence of an infringement and whether the commitments comply with the principle of proportionality. ${ }^{79}$

Commitment decisions may be invoked in private enforcement in various scenarios:

Tort actions based on unlawful behaviours required by a commitment decision:

a) A behaviour imposed by a commitment decision may infringe Articles 101/102, national competition rules, or other rules of EU or national law. The Masterfoods rationale implies that national courts are bound (irrefutable presumption) by the EC/CJEU's determination that the commitments sufficiently dispelled the antitrust concerns identified in the preliminary assessment. ${ }^{80}$ Courts remain free to assess the lawfulness of the behaviours in question under other concerns or other legal provisions. For example, a commitment decision which rests on the finding that a most-favoured nation

graph 100. Judgment of 12 December 2018, Groupe Canal + v. European Commission, T-873/16, EU:T:2018:904, paragraph 99. See also: Caterina Fratea, "Commitment decisions and private actions for damages in EU competition law in light of the Gasorba judgment: a new opening from the Court of Justice of the European Union?", European Competition Law Review 39, no. 12 (2018). ${ }^{78}$ Judgment of 25 November 2014, Orange v. European Commission, T-402/13, EU:T:2014:991, paragraph 31 .

${ }^{79}$ Judgment of 12 December 2018, Groupe Canal + v. European Commission, T-873/16, EU:T:2018:904, paragraphs 36-38, 40-42 and 63. Judgment of 29 June 2010, European Commission v. Alrosa Company Ltd, C-441/07, EU:C:2010:377, paragraph41. See also Judgment of 11 July 2007, Alrosa Company Ltd v. Commission of the European Communities, T-170/06, EU:T:2007:220, paragraphs 86-87.

${ }^{80}$ The same issue does not arise for NCA commitment decisions, relating to Articles 101 and 102 TFEU, because NCAs are prevented from making negative declarations. 
clause in a given standard contract (part of a commitment decision) is compatible with EU Competition Law prevents national courts from finding that it infringes Articles 101/102 TFEU, but does not prevent them from finding that the same clauses infringe other national rules (e.g., unfair trading rules ${ }^{81}$ ). However, to the extent the behaviour in question was strictly required by the commitment decision, the defendant has a legitimate "State action" defence. In such cases, the EC/NCA may be exposed to claims for damages for having obliged an undertaking to infringe EU and/or national law.

b) Tort actions based on the infringements identified in the commitment decision:

Direct/indirect clients or suppliers of a committing undertaking may wish to sue for damages arising from the antitrust infringement identified in the commitment decision's preliminary assessment (i.e. a follow-on action to a commitment decision). In Gasorba, the CJEU clarified that, under the principles of sincere cooperation, effectiveness and uniform application of EU Law, national courts must "take into account" the EC's preliminary assessment and "regard it as an indication, if not prima facie evidence, of the anticompetitive nature" of the practice in question. ${ }^{82}$ While the wording could have been clearer, this seems to mean the burden of proof shifts to the commitment undertaking to prove the behaviour identified in the preliminary assessment did not infringe the TFEU. ${ }^{83}$ In other words,

\footnotetext{
${ }^{81}$ See the example of article 7(1)(a) of Portuguese Decree-Law 166/2013, of 27 December (as last revised by Decree-Law 128/2019, of 29 August).

${ }^{82}$ Judgment of 23 November 2017, Gasorba SL and Others v. Repsol Comercial de Productos Petroliferos SA, C-547/16, EU:C:2017:891, paragraph 29. AG Kokott Opinion delivered on 14 September 2017, Gasorba SL and Others v. Repsol Comercial de Productos Petroliferos SA, C-547/16, ECLI:EU:C:2017:692, paragraph 35. The scope of illegality cannot be determined by the commitments themselves, since these may go beyond what is needed to ensure compliance with the law.

${ }^{83}$ This interpretation is consistent with the case-law on the legal effects of commitment decisions in contractual disputes involving the committing undertaking. A French court of appeal had already interpreted the law in this way - see: Tribunal de Commerce de Paris, $15^{\mathrm{e}}$ chambre, 30 March 2015, DKT v. Eco Emballages and Valorplast (RG 2012000109), overturned in Paris, Pôle 5, ch. 4, Judgment of 20 December 2017 (15/07266). On precedents in Hungary, see: Bodnár, "Hungary", 130 and 149. For a description of actions filed in Spain following the Repsol commitment decision, see Juan Delgado Urdanibia and Eduardo Pérez Asenjo, "Economic evidence and the quantification of damage in competition cases in Spain", in Private Enforcement of Competition Law, eds. Luis Antonio Velasco San Pedro et al. (Valladolid: Lex Nova, 2011), 209.
} 
in follow-on actions, EC commitment decisions have the same value as infringement decisions adopted by NCAs of other MS.

It is not clear whether similar legal consequences derive from commitment decisions adopted by NCAs (relating to Articles 101/102 TFEU), but it would be odd to interpret EU law as harmonising the legal effects of EC/NCA decisions declaring infringements, while allowing different effects for preliminary findings of infringements in EC and NCA commitment decisions.

c) Contractual disputes based on behaviour required by a commitment decision:

Clients/suppliers of a committing undertaking may find that the latter is bound by an EC or NCA commitment decision which requires it to no longer comply with contractual obligations it had entered into with them, and which it was not entitled to unilaterally and freely withdraw from. Those contractual obligations might have stopped being complied with prior to the commitment decision. If they sue the committing undertaking, they may be faced with the following defence: (a) in what concerns effects after the commitment decision, the undertaking is legally required by the commitment decision to adopt that behaviour, and so cannot be held liable for damages; and (b) in what concerns effects both prior to and following that decision, the contractual obligations in question already infringed EU Competition Law, as identified in the preliminary assessment, and were null and void.

The Court has twice looked at these situations. In Alrosa,${ }^{84}$ De Beers was prevented by the commitment decision from complying with its supply contract with Alrosa, and Alrosa lost the annulment proceedings it filed before the CJEU (which disagreed with the GCEU). In Groupe Canal,$+{ }^{85}$ the Commission was concerned with absolute territorial protection clauses in Paramount's exclusive distribution agreements, and the commitment decision required their elimination. The French exclusive distributor appealed the commitment

\footnotetext{
${ }^{84}$ Judgment of 11 July 2007, Alrosa Company Ltd v. Commission of the European Communities, T-170/06, EU:T:2007:220. Judgment of 29 June 2010, European Commission v. Alrosa Company Ltd, C-441/07, EU:C:2010:377. AG Kokott's Opinion delivered on 17 September 2009, European Commission v. Alrosa Company Ltd, C-441/07, EU:C:2009:555, paragraph 3.

${ }^{85}$ Judgment of 12 December 2018, Groupe Canal + v. European Commission, T-873/16, EU:T:2018:904 (see, in particular, paragraph 27).
} 
decision, but did not persuade the GCEU that the clause did not infringe Article 101(1) or that it complied with Article 101(3). An appeal is pending. ${ }^{86}$

Unsurprisingly, the Court does not want commitment decisions to become "get out of jail free" cards for undertakings who infringe Articles 101/102 TFEU. But it is also not too worried about protecting undertakings which enter into anticompetitive agreements and then seek to enforce them in court. ${ }^{87}$ An undertaking subject to a commitment decision cannot invoke the obligations imposed upon it, in the commitment decision, to escape contractual liability. The decision may prevent it from adopting the behaviour it was contractually required to adopt, but it does not prevent it from compensating its counterparty for breach of contract (principle of contractual freedom, if the contract did not include some applicable exception, e.g. force majeure). But this assumes the clause was valid, which is the crux of the matter. If the preliminary assessment determined the clause was invalid (this assessment is, in principle, specific to the market and context of the EC's assessment), the national court must consider it an indication of the existence of the infringement. ${ }^{88}$

d) Disputes based on infringements of a commitment decision:

There may be follow-on cases (injunctions or actions for damages) based on infringements of EC or NCA commitment decisions. ${ }^{89}$ There are already examples of attempts to use commitment decisions in this way, ${ }^{90}$ but no successful one is known.

\footnotetext{
${ }^{86}$ Case C-132/19 P Groupe Canal + v. European Commission.

${ }^{87}$ See AG Kokott Opinion delivered on 17 September 2009, European Commission v. Alrosa Company Ltd, C-441/07, EU:C:2009:555, paragraph 61.

${ }^{88}$ Judgment of 12 December 2018, Groupe Canal + v. European Commission, T-873/16, EU:T:2018:904, paragraphs 100-102. The GCEU referred to Gasorba, suggesting the same legal effects apply here (prima facie evidence), but it did not use the exact same language. This case showed it may be a risky move for the other contractual party to seek annulment of the commitment decision, instead of simply suing before the national court (and hoping there is no referral). Indeed, the GCEU ended up clarifying that Groupe Canal + could not claim, in this case, that the requisites of Article 101(3) were met, and even that damage resulting from loss of clients in France could be offset by new clients from other MS - see T-873/16, cit., paras 67-72.

${ }^{89}$ AG Kokott Opinion delivered on 14 September 2017, Gasorba SL and Others v. Repsol Comercial de Productos Petroliferos SA, C-547/16, ECLI:EU:C:2017:692, paragraph 35.

${ }^{90}$ See, e.g., for Portugal: Judgment of the Porto Appeal Court of 27 May 2013, [B] v. [C] (1569/11.0TJPRT.P1).
} 


\section{Ways out of binding effect of decisions}

Although doubts were raised in several MS about whether this obligation included in the Damages Directive was compatible with their Constitution (because, in some MS, it is unheard of for national courts to be bound to the ruling of another court, much less to an unchallenged administrative decision), all seem to have correctly transposed the provision into their legal orders. However, some MS may be preparing to argue that there are limitations which are not reflected in the letter of their transposition. ${ }^{91}$ This is certainly one of the Directive's most controversial provisions, and challenges to it are more than likely.

There are, arguably, at least 3 legal grounds which could be invoked as exceptions to the legally binding effect of res judicata public enforcement decisions of the respective MS:

(i) Argue that Article 9(1) of the Damages Directive violates fundamental rights recognised in the EU legal order (access to justice, right to a fair hearing by an independent and impartial tribunal) and is invalid. Since national courts are not allowed to control the validity of a provision of EU Law, ${ }^{92}$ this path requires a referral to the CJEU. To the extent the provision has been transposed in national law, a parallel argument about the national provision is also required.

(ii) Argue that Article 9(1) and its transposition violate the same fundamental rights recognised in the national legal order. This argument rests on an assessment of compatibility with the MS Constitution (and with the ECHR) and on the theory of the limits to the primacy of EU Law.

(iii) Argue that, although the defendant exhausted his rights of appeal, the EU/MS review courts infringed EU Law. Primacy and uniform application of EU Law, and the duty of sincere cooperation, arguably require the national court faced with a follow-on action in such a case to submit a referral to the CJEU (at the very least, until this is clarified by the CJEU, because there are doubts about the interpretation of Article 9(1) in this scenario).

\footnotetext{
${ }^{91}$ See, in particular, Italy: Article 7 of Legislative Decree No. 3/ 2017; and Susanna Lopopolo, "Italy", in The EU Antitrust Damages Directive: Transposition in the Member States, org. Barry Rodger, Miguel Sousa Ferro, and Francisco Marcos (Oxford: Oxford University Press, 2018),221. ${ }^{92}$ Judgment of 22 October 1987, Foto-Frost v. Hauptzollamt Lübeck-Ost, 314/85 EU:C:1987:452.
} 
A part of this debate on compliance with fundamental rights is the same for the binding effect of EC decisions, which seems to have been peacefully accepted in national courts. ${ }^{93}$ It may potentially lead to conflicting positions by the Supreme/Constitutional courts of each MS, the ECHR and the CJEU. The CJEU's position must be harmonious with its position on absence of infringement of fundamental rights in Masterfoods (even though not all the reasoning is transposable). ${ }^{94}$ Ultimately, the primacy of EU Law may be jeopardised, with MS courts refusing to comply with this obligation of EU Law and injured parties having no effective means of recourse to force compliance or to obtain compensation for this infringement of EU Law.

\section{Conclusion}

This article has shown that a lot has already been determined, in EU law and case-law, about the binding effects of findings of infringements in antitrust public enforcement proceedings. While commentators' attention tends to focus on positive declarations of antitrust infringements, there is already much to be said about negative declarations, commitment, state aid and merger decisions, as well as about non-final decisions and ongoing investigations. The emerging picture is that of a largely harmonious caselaw across the board, which sets off from the same general principles to arrive at the same solutions for identical situations.

Being aware of the clarifications provided by the case-law is important, not only to avoid overestimating the issues of succession of laws which some may erroneously imagine to arise from the entry into force of the Damages Directive, but also to grasp the full extent to which national

\footnotetext{
${ }^{93}$ For Portugal, see Judgment of the Lisbon Appeal Court of 9 April 2013, [J] v. [P] (Gas bottles) (627/09.5TVLSB.L1-7).

${ }^{94}$ Judgment of the Court of 14 December 2000, Masterfoods Ltd v. HB Ice Cream Ltd, Case C-344/98, EU:C:2000:689. According to the Court, given the judicial means available to undertakings to challenge Commission decisions, directly (before the GCEU, and then CJEU) and indirectly (before the CJEU, via referral), the binding effect of Commission decisions upon national courts does not infringe the fundamental right of access to justice, even considering the limited review by the Court over complex economic assessments - see Judgment of 6 November 2012, Europese Gemeenschap v. Otis NV and Others, Case C-199/11, EU:C:2012:684, paragraphs 55-63. AG Cruz Villalón's Opinion delivered on 26 June 2012, Europese Gemeenschap v. Otis NV and Others, C-199/11, EU:C:2012:388, paragraphs 50 and 55. It should be noted that the Court did not explicitly address the concern for the independence of the judiciary - on this, see AG Cruz Villalón's Opinion delivered on 26 June 2012, Europese Gemeenschap v. Otis NV and Others, C-199/11, EU:C:2012:388, paragraphs 43-44.
} 
sovereignty has already been limited in this regard, and the answers which have already been provided to the counterarguments that are likely to be raised by those who feel that such encroachments have gone too far. That being said, several of the legal controversies discussed in this article are far from settled, and will no doubt be the focus of much debate in the years to come.

\section{Bibliography}

Andersson, Torbjörn. "The binding effects of decisions and judgments under EU competition law". In EU Competition Litigation: Transposition and First Experiences of the New Regime, edited by Magnus Strand, Vladimir Bastidas, Marios C. Iacovides. England: Hart, 2019.

Ashton, David. Competition Damages Actions in the EU: Law and Practice, $2^{\text {nd }}$ edition. United Kingdom: Edward Elgar, 2018.

Bernatt, Maciej and Maciej Gac. "Poland". In The EU Antitrust Damages Directive: Transposition in the Member States, organised by Barry Rodger, Miguel Sousa Ferro, and Francisco Marcos, 290-303. Oxford: Oxford University Press, 2018.

Blažo, Ondrej. "Slovakia”. In Implementation of the EU Damages Directive in Central and Eastern European Countries, edited by Anna Piszcz, 247-262.Warsaw: University of Warsaw Faculty of Management Press, 2017.

Bodnár, Peter Miskolczi. "Hungary". In Implementation of the EU Damages Directive in Central and Eastern European Countries, edited by Anna Piszcz, 127-157.Warsaw: University of Warsaw Faculty of Management Press, 2017

Bucan Gutta, Nina. The Enforcement of EU Competition Rules by Civil Law. Maklu Pub, 2014.

Chagny, Muriel. "France". In The EU Antitrust Damages Directive: Transposition in the Member States, organised by Barry Rodger, Miguel Sousa Ferro, and Francisco Marcos, 101-123. Oxford: Oxford University Press, 2018.

Costeira, Maria José. "A transposição da Diretiva Private Enforcement: Perspetiva crítica”, (2017) 3(2) UNIO - EU Law Journal 3, no. 2 (2017): 148-157.

Coutinho de Abreu, Jorge Manuel. Responsabilidade Civil dos Administradores de Sociedades, 2. a edição. Coimbra: Almedina, 2010.

Doherty, Barry and Anne Fitzpatrick. "Courage to change? The rocky road to Directive 2014/104/ EU and the future of private competition law enforcement in Ireland". Irish Journal of European Law 18, no. 2 (2015): 15.

Fratea, Caterina. "Commitment decisions and private actions for damages in EU competition law in light of the Gasorba judgment: A new opening from the Court of Justice of the European Union?”. European Competition Law Review 39, no. 12 (2018). 
Frese, Michael J. "Civil liability for single and continuous infringements". World Competition 41, no. 2 (2018): 179-195.

Geradin, Damien and Evi Mattioli. "The transactionalization of EU competition law: A positive development?”. TILEC Discussion Papers 2017, no. DP 2017-035. https:// www.tilburguniversity.edu/research/institutes-and-research-groups/tilec/research/ discussion-papers/2017.

Henriksson, Lars. "Sweden". In The EU Antitrust Damages Directive: Transposition in the Member States, organised by Barry Rodger, Miguel Sousa Ferro, and Francisco Marcos, 358-377. Oxford: Oxford University Press, 2018.

Jerneva, Julija and Inese Druviete. "Latvia". In Implementation of the EU Damages Directive in Central and Eastern European Countries, edited by Anna Piszcz, 157-178. Warsaw: University of Warsaw Faculty of Management Press, 2017.

Kersting, Christian. "Liability of sister companies and subsidiaries in European competition law”. Zeitschrift für das gesamte Handelsrecht und Wirtschaftsrecht 182 (2018): 8-31.

Kersting, Christian. "Private law liability of the undertaking pursuant to Article 101 TFEU”. Wirtschaft und Wettbewerb (2019): 290. https://ssrn.com/abstract=3439973.

Kreuschitz, Viktor and Nuria Bermejo. "The role of national courts in the enforcement of the European state aid rules". In EU Competition and State Aid Rules: Public and Private Enforcement, edited by Vesna Tomljenovic et al., 221-252. Berlin: Springer, 2017.

Lopopolo, Susanna. "Italy". In The EU Antitrust Damages Directive: Transposition in the Member States, organised by Barry Rodger, Miguel Sousa Ferro, and Francisco Marcos, 209-231. Oxford: Oxford University Press, 2018.

Lucey, Mary Catherine. "Ireland”. In The EU Antitrust Damages Directive: Transposition in the Member States, organised by Barry Rodger, Miguel Sousa Ferro, and Francisco Marcos, 193-208. Oxford: Oxford University Press, 2018.

Mikelènas, Valentinas and Rasa Zaščiurinskaitè. "Lithuania". In Implementation of the EU Damages Directive in Central and Eastern European Countries, edited by Anna Piszcz, 179-210. Warsaw: University of Warsaw Faculty of Management Press, 2017.

Mircea, Valentin. "Romania”. In Implementation of the EU Damages Directive in Central and Eastern European Countries, edited by Anna Piszcz, 237-246. Warsaw: University of Warsaw Faculty of Management Press, 2017.

Petr, Michal. "Czech Republic". In Implementation of the EU Damages Directive in Central and Eastern European Countries, edited by Anna Piszcz, 85-108. Warsaw: University of Warsaw Faculty of Management Press, 2017 
Piroddi, Paola. "Damages actions for infringement of competition rules and the right to a fair trial under article 6(1) ECHR". In Private Enforcement of Competition Law, edited by Luis Antonio Velasco San Pedro et al., 441-454 Valladolid: Lex Nova, 2011.

Piszcz, Anna. "Implementing the rules of the Damages Directive on joint and several liability: The SME derogation". In EU Competition Litigation: Transposition and First Experiences of the New Regime, edited by Magnus Strand, Vladimir Bastidas, Marios C. Iacovides. England: Hart, 2019.

Ramos, Maria Elisabete. "Situação do 'private enforcement' da concorrência em Portugal”. Revista de Concorrência e Regulação, no. 27-28 (2016): 27-83.

Rodger, Barry. "United Kingdom". In The EU Antitrust Damages Directive: Transposition in the Member States, organised by Barry Rodger, Miguel Sousa Ferro, and Francisco Marcos, 378-407. Oxford: Oxford University Press, 2018.

Schaub, Alexander. "Panel one discussion: Compatibility, efficiency, legal scrutiny". In European Competition Law Annual 2000: The Modernisation of EC Antitrust Policy, edited by Claus-Dieter Ehlermann and Isabela Atanasiu. England: Hart, 2001.

Urdanibia, Juan Delgado and Eduardo Pérez Asenjo. "Economic evidence and the quantification of damage in competition cases in Spain". In Private Enforcement of Competition Law, edited by Luis Antonio Velasco San Pedro et al., 205-214. Valladolid: Lex Nova, 2011.

Vlahek, Ana and Klemen Podobnik. "Slovenia". In Implementation of the EU Damages Directive in Central and Eastern European Countries, edited by Anna Piszcz, 263-296. Warsaw: University of Warsaw Faculty of Management Press, 2017.

Whish, Richard. "Damages actions in the courts of England and Wales". In Private Enforcement of Competition Law, edited by Luis Antonio Velasco San Pedro et al., 155-165. Valladolid: Lex Nova, 2011. 